\title{
Historical Aspect of Inflation in Pre and Post Covid- 19 Pandemic in Pakistan
}

\author{
Muhammad Asif Amjad \\ Ph.D. Scholar \\ Department of Economics and Statistics \\ Universityof Management and Technology, Lahore \\ m.asifamjad22@gmail.com
}

\author{
Nabila Asghar \\ Associate Professor \\ Department of Economics and Business Administration \\ Division of Management and Administrative Science \\ Universityof Education Lahore \\ nabeela.asghar@ue.edu.pk

\section{Hafeez-ur-Rehman} \\ Professor/Chairperson \\ Department of Economics and Statistics \\ Universityof Management and Technology, Lahore \\ hafeez.rehman@umt.edu.pk(CA)
}

\begin{abstract}
Covid-19 Pandemic proved to be very dangerous and catastrophic in the entire history of mankind. It affected every corner of the world within less than a year. It changed the lifestyle and paralyzed all modern technology and killed millions of people around the globe. This study presents the historical overview of major world pandemics and Covid-19 as well. It also examines the impact of Covid-19 pandemic on inflation and on other sectors of Pakistan's economy. The results reveal that covid-19 is the main culprit responsible for double digit inflation and slow economic growth in Pakistan. The present study explores that during 2020 high inflation was due to world lock down while in 2021 the main cause of inflation was persistent increase in oil prices, food shortage, political instability in Afghanistan and devaluation of Pakistan's rupee. The results indicate that Covid-19 affects adversely every sector of Pakistan economy. The study suggests

(C) 2021 The Authors, Published by The Women University Multan. This is an Open Access Article under the Creative Common Attribution Non-Commercial 4.0

Date of Acceptance: 01 December 2021

Available Online: 28 December 2021
\end{abstract}


that government should pay proper attention to health of the general public and implement suitable policies to stabilize the economic growth.

Keywords: Inflation, Pandemic, Pakistan Economy, Covid-19 outbreaks

\section{Introduction}

Human life came into existence millions of years ago. The human life history is full of dangerous pandemics and catastrophes. According to Holy books, the first pandemic Bubonic Plague (Justinian Plague) was recorded in $540 \mathrm{CE}$ in Ethiopia (African Region). Its spread range was too fast as it caught the whole region along with both sides of the Mediterranean Sea in less than a year. Due to this Pandemic, millions of people lost their lives and faced severe famine (Frith, 2012). In the $14^{\text {th }}$ century, the second plague named as Black Death occurred in Europe. This pandemic was so hazardous that people had not the proper time to bury the dead bodies of their relatives and were thrown into large pits and streets. This second pandemic also caused the great social and economic disturbance. The crop harvesting and trade were much affected adversely due to shortage of workers which caused a shortage of food and manufactured goods (Zeigler, 1969). The third Plague reemerged in 1855 in Yunnan (China Province) and spread in the whole world by sea routes. More than 15 million people died from this Pandemic (WHO, 2012).

In the $20^{\text {th }}$ century, three major pandemics like influenza occurred. The first pandemic occurred in 1918 which was called Spanish flow caused by the $\mathrm{A}(\mathrm{H} 1 \mathrm{~N} 1)$ virus. According to the World Bank report, the Spanish flow pandemic cost about $\$ 800$ billion and killed about 20-50 million people (Brahmbhatt, 2005). The second pandemic occurred in 1957 called as Asian Flu caused by the A(H2N2) virus. Due to the advancement of scientific tech nology this virus was quickly identified. However, Asian flu was not too much destructive as the Spanish flu. In 1968 Hong Kong Flu was detected which was caused by $\mathrm{A}(\mathrm{H} 3 \mathrm{~N} 2)$ virus and 1-4 million people lost their lives. Apart from these three pandemics a few 
small pandemics also emerged in the $20^{\text {th }}$ century for example Swine flu threat (1976), Russian Flu (1977), and Avian Flu(1997).

In the $21^{\text {st }}$ century, five Pandemic outbreaks were observed. Severe Acute Respiratory Syndrome (SARS) coronavirus was found in China in 2002 (Peiris \& Poon, 2008). Avian flu (N1H1) also called "bird flu" was detected in California in 2009 (Lycett et al., 2019). Middle East Respiratory Syndrome (MERS) was found in Saudi Arabia in 2012(Rasmussen et al., 2019). Ebola Virus Disease (EVD) was detected in West Africa during 201314(Cenciarelli et al., 2015).

In 2019 one of the worst diseases was found in Wuhan city of China and it was reported by the WHO on December 31, 2019, as the respiratory illness caused by a novel coronavirus (SARS-Co V2) formerly called nCovid-19. On March 11, 2020, WHO declared this disease as an international Pandemic and imposed a health emergency. The speed of the spread of this virus was so fast that it reached to every corner of the world within two months. At the end of March 2020, more than half of the world was badly affected and forced to impose lockdown and health emergency. This lockdown affected all macroeconomic variables such as labor market, income level of people, services sector, traveling and tourism sector, manufacturing sector, etc in all over the world. The production and distribution of all goods and services were interrupted and the lifestyle was also affected severely. Covid 19 not only crashed the whole world's economy but also swallowed 5.1 million people till November 15, 2021 (WHO Coronavirus Disease (COVID-19) Dashboard). Its mortality rate was very high as compare to all other pandemics. Figure 1 presents the death rate from January 01 2020 to January 05,2021 in the world.

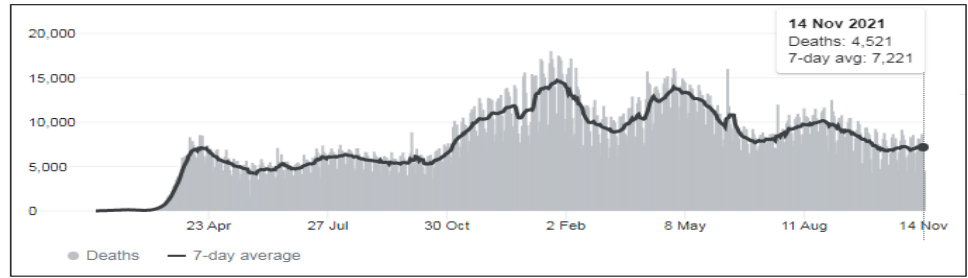

Figure 1 Global Death Rate (Source: JHU CSSE COVID-19 Data) 
In developing countries, all economies are interdependent to each other. The process of economic development is not entirely determined by domestic policies but it is also influenced by global policies (Rusdy, 2006). The high mortality rate around the world also affected the process of economic growth adversely. Figu re 2 presents total death around the world recorded by WHO (January 05, 2021).

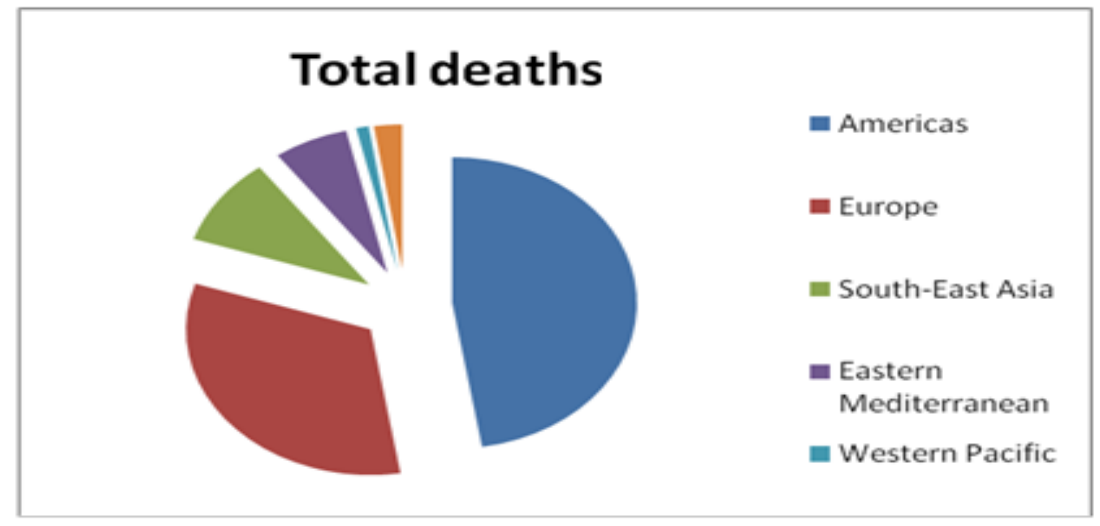

Figure 2 Global WHO Region total Deaths (Source: WHO)

The figure 2 shows that American and European countries were severely and relatively high death rate.

Pakistan, being a developing country, is connected with Europe, America, and China (Origin of Covid-19) and has strong relationship with European countries (by the Commonwealth, CENTO, SEATO alliances and Colombo Plan, etc) and China (China-Pakistan Economic Corridor Project). Over time these countries have been providing aid and technical assistants to Pakistan (Iqbal, 1974; Kanwal et al., 2020).

According to International Labor Organization (ILO) Covid-19 affected the labor markets of world badly. It not only affected the production of goods and services (Supply-side) but also affected the consumption and investment of goods and services (demand side). The world economy lost trillions of dollars. Pakistan's economy is also severely affected by the covid-19 pandemic. It adversely affected all sectors of Pakistan economy especially 
service sector, trade, hospitality, manufacturing sector, tourism sector, banks, healthcare, hotels, education, real estate, and others.

The present study is organized as follows. Section 2 presents the over view of research methods. Brief history of inflation in Pakistan before Covid-19 is presented in section 3. The description of inflation in Pakistan after Covid-19 is given in section 4. Sector wise implications of Covid-19 is presented in section 5. The last section concludes.

\section{Overview of Research Methods}

Historically, several techniques have been used for observing the impact of pandemics. The simulation model is applied to study the economic impact of the pandemic in earlier studies. In neoclassical growth model, the extension of the standard difference indifference approach was applied to measure the impact of the Spanish flu (1918) pandemic in the Swedish economy (Karlsson et al. 2014). Oxford Economic Forecasting model was applied to study the impact of Avian Flu Pandemic (1997) in Asian economies which analysed the supply and demand side aftershocks (Bloom et al. 2005). G-Cubed model was projected to estimate the economic impact of the SARS (2002) pandemic (Lee \&McKibbin, 2004). Novel Covid-19 is a new pandemic; a lot of scientific studies have been carried out on the impact of infection on the human body and possible cures of infection. There is no proper study available which has quantitatively estimated the intensity of adverse impact of Covid-19. The present study uses descriptive analysis to examine the historical aspect of inflation in Pakistan before and after Covid-19.

\section{Inflation in Pakistan Pre Covid-19}

After partition, Pakistan was considered as the Asian Tiger in era of $1960 \mathrm{~s}$ and it showed extraordinary performance in the agriculture and industrial sectors. It set an example for other developing nations of the world. In the decade of 1960, five year plans were implemented which enjoyed domestic growth rate by more than 6.7 percent per year (Hasan, 1997). Inflation in Pakistan had been a major problem in early 60s. it rose 11.9 
percent in 1970s which fell down about 7.5 percent in the decade of 1980s. After 1971, Pakistan PPP government nationalized all financial intuitions and industries (Pakistan Economic Survey, 2010-2011). Due to poor management of government officials, oil price shocks in 1973, flood, and pest attacks damaged the crops that increased inflation to 11.9 percent (Kemal \& Qadir, 2005; Khan, 2009).

In 1977, General Zia U1 Haq imposed martial law. In Zia era, Pakistan played a key role in several ways in the development process of Pakistan economy. The economic growth rate was very impressive which helped in reducing the inflation. As a result, inflation rate declined to 7.5 percent in 1980s. In 1988, after General Zia U1 Haq regime, Pakistan had pass through four general elections in which both Benazir Bhutto and Nawaz Sharif played musical chair. Since none of the elected governments could succeed in completing their full term. There were more than a few caretaker governments. Moeen Quresihi (retired Vice President of World Bank) under the leadership of Meraj Khalid, who had Shahid Javed Burki (a serving World Bank vice president) as finance advisor, had been very controversial. In this period, the International Monetary Fund (IMF) initiated the Structural Adjustment Program (SAP). Pakistan became the member of the SAP of IMF. Due to SAP the economic growth rate of Pakistan fell 3 to 4 percent; poverty level increased up to 33 percent, inflation reached in the double digit and foreign debt increased sharply (Zaidi, 2006).

After 1999, Pervez Musharraf took control of the country and imposed martial law. This period is called as the magical growth period. In this regime GDP uplifted from $2.1 \%$ to $7 \%$ till 2007 . In this period, inflation rate declined from double digit to $5.5 \%$. In this period there was attractive environment for foreign investors to invest in Pakistan (Shah, 2014; Khan \& Joseph, 2008).

During 2008-2013, once again PPP government came into power. It was a challenge for the PPP government to keep the flow of former government. But unfortunately, PPP government failed to keep the pace of economic growth which resulted in a record high inflation in the history of Pakistan. In this period, an average inflation rate remained $13.3 \%$ throughout the period due to high energy prices in international market (Anwar et al. 2017). This 
period was considered one of the worst period of Pakistan's history in terms of bad governance, tax reforms, and corruption.

After of PPP government PML-N took control of Pakistan economy for the period 2013-2018. In this period, GDP growth rate increased from $3.5 \%$ to $5.83 \%$ till 2018. After 2018 Pakistan Tehreek -e-Insaf (PTI) came into power. In the first year of present government, GDP growth rate declined from $5.83 \%$ to $0.98 \%$ (World Bank) and inflation increased from 3.92\% to 7.33\% (IMF).

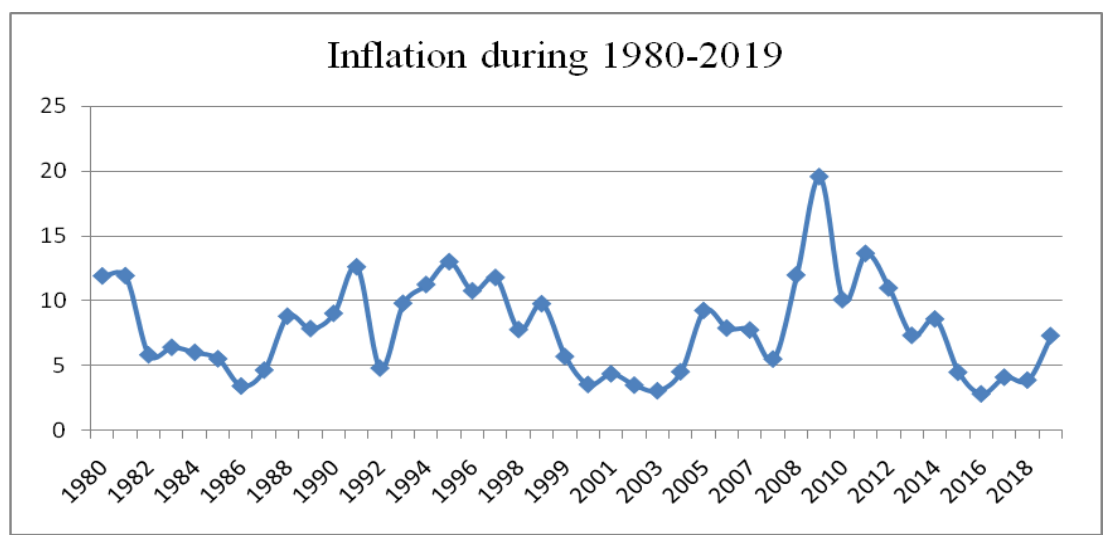

Figure 3 Inflation Rates in Pakistan during 1980-2019 Source: IMF World Economic Outlook Data October 2021

\section{Inflation in Pakistan Post Covid-19}

In early 2020, Covid-19 paralyzed the falling economy of Pakistan. United Nations Economic \& Social survey of Asian and Pacific (ESCAP) 2020 projected that Covid-19 Pandemic would have adverse socio-economic consequences on all over the world. It affected across-border activities especially in trade, tourism, and financial linkages (UN 2020). Within less than one year this pandemic paralyzed the whole world.

In the first year of Covid-19 the inflation rate in Pakistan increased and reached to $10.7 \%$ in spite of the fact that crude oil prices remained lowest at $\$ 39.68$ per barrel in international market. The inflation rate in Pakistan was much higher than in all neighboring countries. It was quite difficult to achieve stable 
economic growth in such high inflation. Monetary policy failed to provide any fruitful results related to inflation in Pakistan. Table 1 shows the comparison of inflation rate of Pakistan and other south Asian countries.

Table 1: Inflation rate, average consumer prices (Annual percent change)

\begin{tabular}{|c|c|c|c|c|c|c|c|}
\hline & $\begin{array}{c}\text { Banglad } \\
\text { esh }\end{array}$ & $\begin{array}{c}\text { Bhut } \\
\text { an }\end{array}$ & $\begin{array}{c}\text { Indi } \\
\text { a }\end{array}$ & $\begin{array}{c}\text { Maldiv } \\
\text { es }\end{array}$ & $\begin{array}{c}\text { Nep } \\
\text { al }\end{array}$ & $\begin{array}{c}\text { Pakist } \\
\text { an }\end{array}$ & $\begin{array}{c}\text { Sri } \\
\text { Lanka }\end{array}$ \\
\hline 2017 & 5.4 & 4.3 & 3.6 & 2.3 & 4.5 & 4.1 & 6.6 \\
\hline 2018 & 5.8 & 3.7 & 3.4 & 1.4 & 4.1 & 3.9 & 4.3 \\
\hline 2019 & 5.5 & 2.8 & 4.8 & 1.3 & 4.6 & 6.7 & 4.3 \\
\hline 2020 & 5.6 & 4.2 & 6.2 & -1.6 & 6.1 & 10.7 & 4.6 \\
\hline 2021 & 5.6 & 6.3 & 5.6 & 1.4 & 3.6 & 8.9 & 5.1 \\
\hline $\begin{array}{c}2022 \\
\text { F }\end{array}$ & 5.7 & 6.9 & 4.9 & 2.3 & 5.7 & 8.5 & 6.2 \\
\hline $\begin{array}{c}2023 \\
\text { F }\end{array}$ & 5.8 & 5.1 & 4.3 & 1.9 & 5.7 & 7.6 & 6.5 \\
\hline $\begin{array}{c}2024 \\
\text { F }\end{array}$ & 5.6 & 4.4 & 4.1 & 1.8 & 5.6 & 6.5 & 6.2 \\
\hline $\begin{array}{c}2025 \\
\text { F }\end{array}$ & 5.4 & 4.1 & 4 & 2 & 5.4 & 6.5 & 5.8 \\
\hline $\begin{array}{c}2026 \\
\text { F }\end{array}$ & 5.4 & 3.9 & 4 & 2 & 5.4 & 6.5 & 5.2 \\
\hline
\end{tabular}

Source: IMF World Economic Outlook Data October 2021

Table 1 shows Pakistan is the only country among South Asian countries which had faced double-digit inflation. IMF estimated Pakistan's inflation rate at $10.7 \%$ which was a major hurdle in the way of achieving stable economic growth. According to the inflation monitor of the State Bank of Pakistan, the inflation rate of Pakistan was higher among developed and others emerging economies (SBP, April 2020).

Due to Covid-19 outbreaks and political instability, Pakistan initially banned all kinds of trade with China. It disturbed the supplies of raw material because most of the raw materials of industries were imported from China. Pakistan already banned 
trade with India due to the Kashmir issue, so Pakistani manufacturers moved to alternative sources (South Korea, Taiwan) which increased the cost of production of manufactured goods and caused high inflation in Pakistan's economy (Sareen, 2020).

At the end of 2020, Covid-19 vaccine trail was completed. In February, 2021 Pakistan received 500,000 doses from China (Gul, February 02, 2021). Apart from Pakistan, all other countries also introduced vaccine to their public. According to The New York Times (November 17,2021) more than 4.12 billion people got complete doses of vaccine which was $53.7 \%$ of world total population. Now most of the countries are opening their borders for trade and business activities. Due to rapid increase in business activities, world demand supply gap emerged and a persistent increase in crude oil prices have caused worldwide inflation. The shortage of food items due to instability in Afghanistan also enhanced inflation in Pakistan. Another important factor which is responsible for high inflation is the devaluation of Pak rupee. The IMF estimated that inflation in Pakistan is as high as $8.9 \%$ at the end October 2021. In the coming years IMF projected inflation rate may be high in Pakistan as compared to other South Asian Countries.

\section{Sector-wise Implications of Covid-19 Pandemic in Pakistan}

\section{Impact on GDP Growth Rate}

The Covid-19 pandemic has spread rapidly all over the world and adversely affected the economic growth. Mohajan (2020) estimated about $\$ 90$ trillion loss of world GDP. Figure 4 shows the world real GDP growth along with regional economic growth for the years 2019,2020 (actual data) and 2021- 2022(IMF forecasting). 


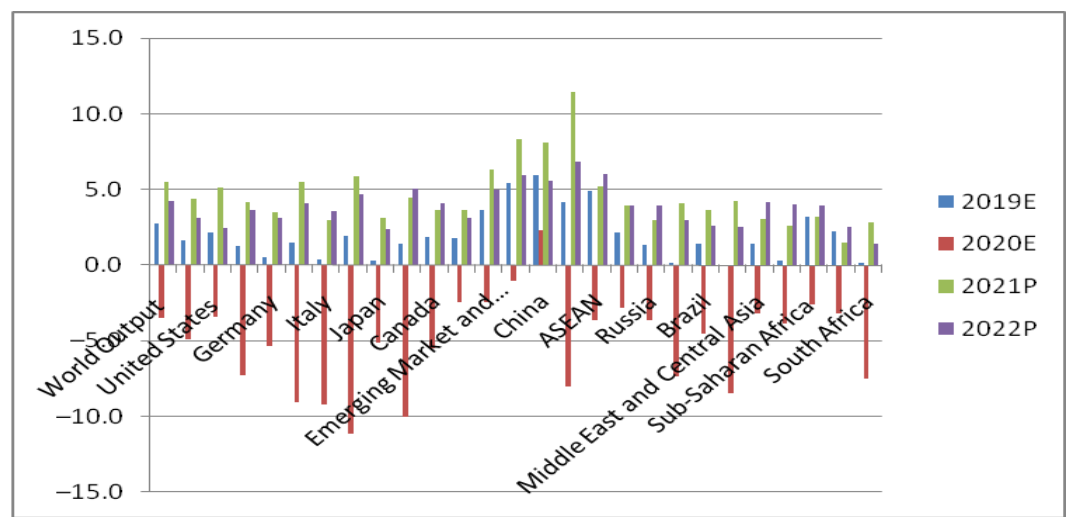

Figure 4 Real GDP Growth of World along with Regional Economies (Sources: IMF 2021)

Figure 4 shows that the world's real GDP was 2.8 percent in 2019 which fell down -3.5 percent in 2020 . The introduction of Covid 19 vaccine was helpful in promoting the economic growth all over the world. The highest GDP growth is being projected in the Asian countries especially in ASEAN, China, and emerging market of developing countries.

Covid-19 outbreak has exerted adverse impact on Pakistan's economy. According to the Economic Survey of Pakistan (201920), Pakistan's real GDP growth rate declined sharply. In 2018, Pakistan's real GDP growth rate was estimated around 5.8\% which declined to -0.4 percent. Pakistan GDP growth rate from 19612022 is presented in figure 5. The data set of annual GDP grow th for the period 1961-2019 was taken from WDI and the remaining data set from the IMF world economic outlook (January 2021). 


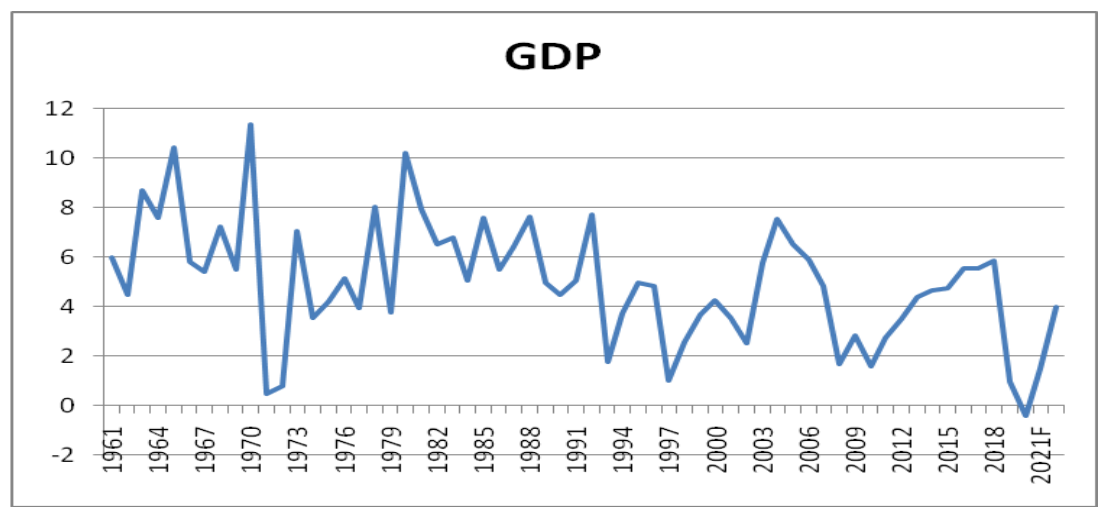

Figure 5 Pakistan's Real GDP Growth over 1960-2020 (Source: WDI, 2019 \& IMF, January 2021)

Figure 5 shows huge ups and downs in economic growth especially in 1971, 1978, and 1994, 1997, 2003, and 2009. These shocks were due to political instability and several other economic problems. Pakistan's GDP growth reached closer to zero due to these shocks but in 2020 , it attained negative value $-0.4 \%$.

In the past couple of months, many international institutions praised Pakistan's action against covid-19 outbreaks. Especially micro and smart lockdown policies of the government of Pakistan have put the economy to the recovery phase. One of the latest reports of Moody's projected that GDP may increase in Pakistan closer to $1.5 \%$ by the end of June 2021. ADB also projected $3.2 \%$ GDP growth rate by the end of 2021(ADB, September 2020).

If we compare Pakistan's real GDP (1.5\%) with world GDP growth rate $(5.5 \%)$ it seems to be an alarming situation for Pakistan's economy. Political instability, rising unemployment, and high inflation are the major factors responsible for slow economic growth in Pakistan. The high current account deficit of Pakistan has also adversely affected the economic growth rate. Figure 6 shows the current account balance as a percentage of GDP for the period 2018 to 2021. 


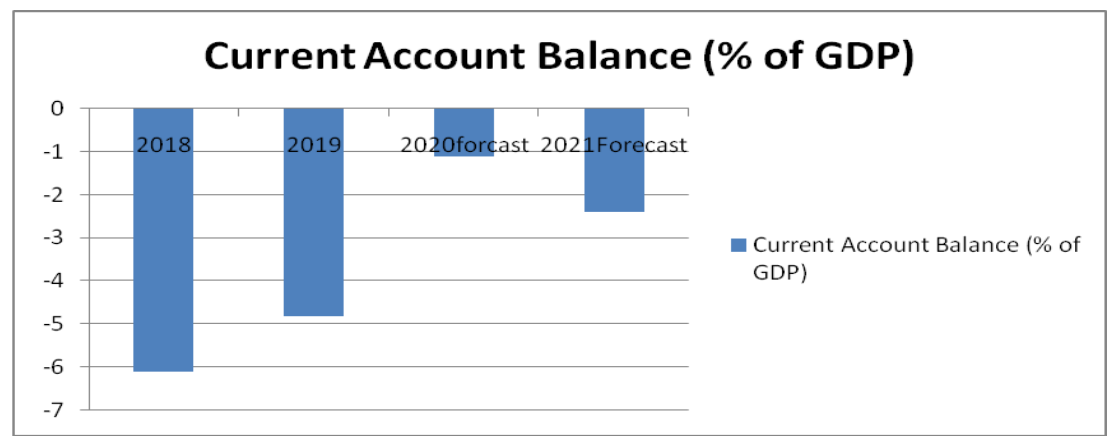

Figure 6 Current Account Balance (Source: ADB September 2020)

Figure 6 shows that after the general election in July 2018 , it was quite difficult for PTI government to finance current account deficit with the internal resources. As a result, within ten months the PTI government moved toward the IMF doorstep for the $13^{\text {th }}$ loan program. This program proved helpful to reduce the fiscal and balance of payment deficit. Pakistan's current account deficit improved rapidly due to sharp decline in oil prices in international market (Zaidi, 2020).

\section{Unemployment and Work Force Migration During Covid-19 Outbreaks}

According to ILO report 2020, Covid-19 outbreaks proved worse than World War II. The half of the world population was under severe lockdown and millions of people have lost their jobs and became unemployed. It was estimated that about 9 to 35 million people may fall below the poverty line ( $\$ 3.3$ per day) in developing countries due to the outbreaks of Covid-19.

The covid-19 pandemic has adversely affected the non-agriculture workers due to lock down and closure of businesses. The intensity of the impact of lock down was very high for daily wage earners, small business holders (shop keepers, taxi drivers, and street vendors, etc). Table 2 presents the employment as a percentage of total population during 2020. 
Table 2 Detail of Employment in Pakistan during 2020

\begin{tabular}{|l|l|l|}
\hline Period & $\begin{array}{l}\text { Employment for Total } \\
\text { Population (\%) }\end{array}$ & $\begin{array}{l}\text { Employed } \\
\text { Labor(Millions) }\end{array}$ \\
\hline $\begin{array}{l}\text { Pre-Covid 19 } \\
\text { (January-March) }\end{array}$ & 35 & 55.74 \\
\hline $\begin{array}{l}\text { Covid Period } \\
\text { (April-July) }\end{array}$ & 22 & 35.04 \\
\hline $\begin{array}{l}\text { Post Covid-19 } \\
\text { (August-Oct) }\end{array}$ & 33 & 52.56 \\
\hline
\end{tabular}

Source: Pakistan Bureau of Statistic 2020

Table 2 shows that before the Covid- 19 pandemic $35 \%$ of the total population about 55.74 million people were working in different sectors. But after the Covid-19 pandemic and lock down it declined to $22 \%$ of the total population which was about 35 million during the first six months. But it was very surprising that after July 2020 almost the $\mathrm{V}$-shaped recovery process started and $33 \%$ of the total population about 52.56 million again started working.

Pakistan is one of the labor exporting countries in the world. About 11 million Pakistani are working abroad. The lockdown and international travel restrictions of domestic and foreign countries exterted adverse effect on overseas Pakistani. According to the Bureau of Emigration and overseas employment more than 50,000 workers failed to visit overseas. Figure 7 shows the total number of emigrants of Pakistan during 2015-2020.

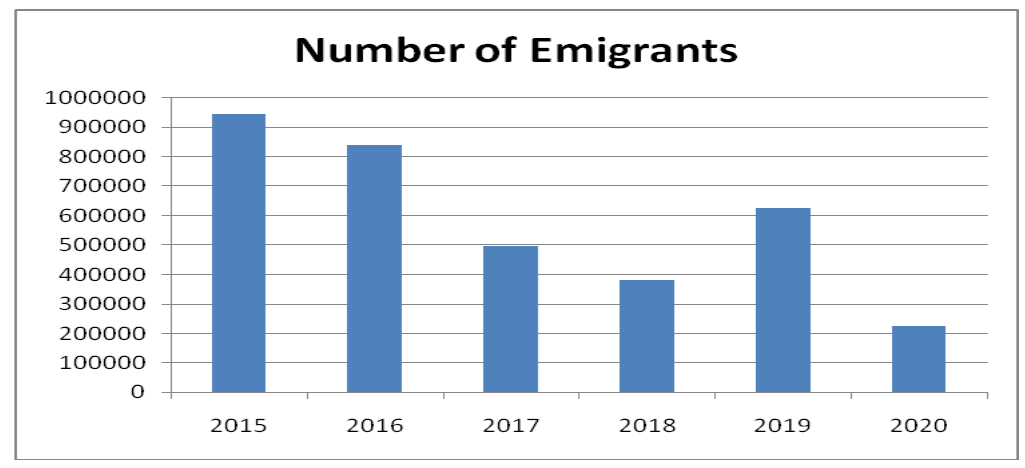


Figure 7 Number of Emigrants (Source: Bureau of Emigration and overseas employment (BE\& OE) Pakistan)

Figure 7 shows that according to Bureau of Emigration and overseas employment (BE \& OE) in 2015 about 946,571 workers were working aboard which decreased gradually in the next proceeding years. By the end of 2020 total number of emigrants declined to 224,705 .

\section{Service Sector of Pakistan}

Usually, the service sector is considered as the engine of economic growth. The service sector played an important role in the development process of Pakistan. The service sector includes four major sectors in Pakistan like Producer services, personal services, social services, and distributed services. These four sectors are further divided into various sub-sectors. In producer services (financial institution), personal services (Entertainment, Ownership, and Dwelling), social services (Public Administration, Defense, Social Community, and Private Services), and Distributed sector (transports, trade sector, Communications, Hotels, and Restaurants) are included (Ahmed \& Ahsan, 2011).

According to the World Bank data sheet of Pakistan, the service sector contributes about 54 percent in GDP and over one-third of the total labor force is employment in this sector. Figure 7 shows the share of the service sector as a percentage of GDP for the period of 1960-2020.

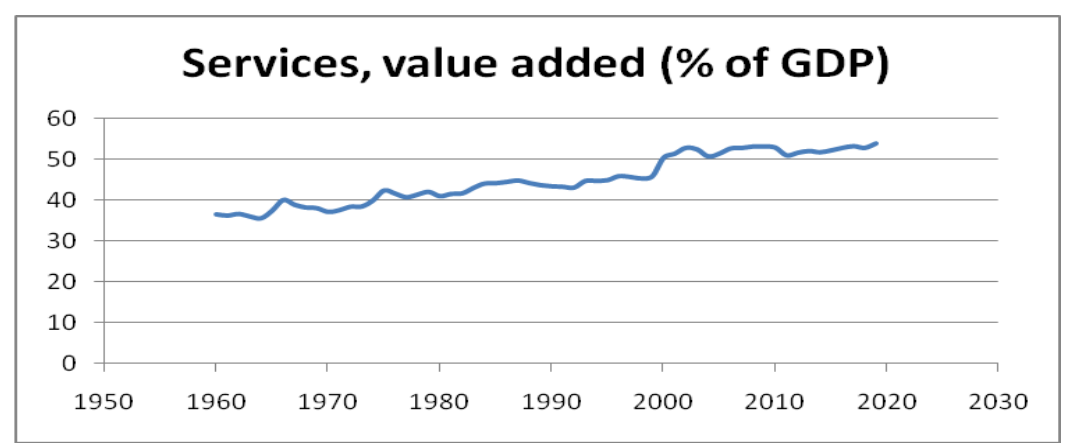


Figure 8 Share of Service in GDP (Source: World Development Indicator

Figure 8 shows that the share of the service sector gradually increases over time. Covid-19 badly affected the service sector and all sub-service sectors adversely in Pakistan. Furthermore, it is estimated about $90 \%$ of hotels rooms have no booking which was the major revenue loss to this industry. While wedding, semin ars, conferences, and events were also canceled or postponed which ultimately affected the hotel's revenues (Javid, 2020).

In 2018 Pakistan's receipts from international tourism were $\$ 818$ million. Due to covid-19 Pandemic and traveling restrictions tourism industry lost $\$ 163.6$ million only in the first three month s (ADB) and about 75,000 people lost their jobs including tour guides, tour operators, hotel staff, travel agents, and drivers, etc.

\section{Foreign Remittances During Covid-19}

Foreign remittances helped to reduce the current account deficit and foreign debt burden. The worker's remittance of November 2019 (Before Covid-19) and December 2020 are presented in figure 9 .

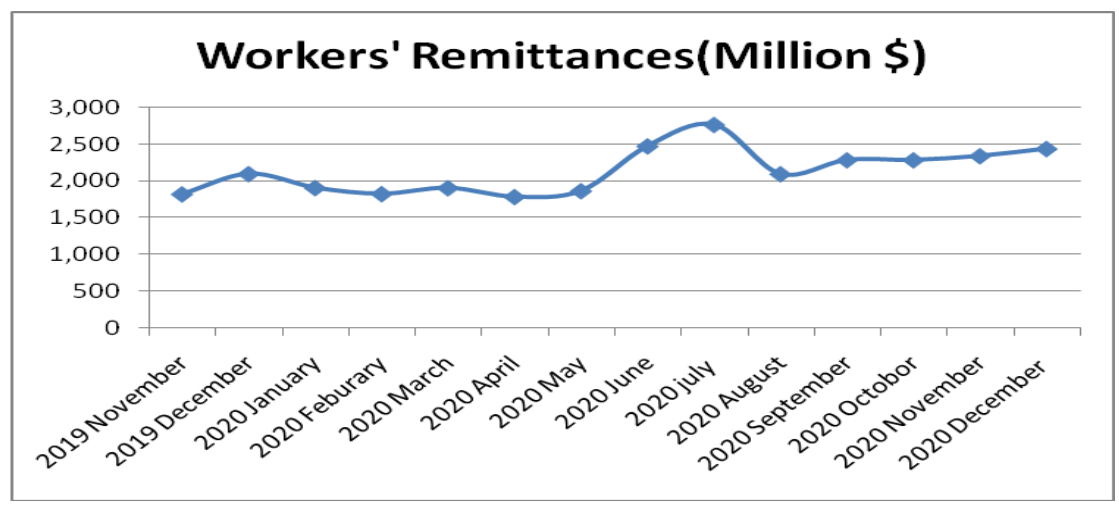

Figure 9 Workers' Remittance (Source: State Bank of Pakistan January, 2021)

Figure 9 shows monthly Worker remittances of Pakistan from November 2019 to December 2020. In December 2019 Pakistan 
received remittances of $\$ 2,097$ million. In the beginning of 2020 intensity of Covid-19 increased which caused the worker remittances to decline gradually. In April when the Covid-19 was touching its highest peak, the foreign remittances declined and reached to $\$ 1785$ million. After April once again it started increasing and by the end of December 2020, foreign remittance s increased \$2437 million.

\section{Conclusions and Policy Recommendations}

Covid-19 has proved to be the globally hazardous pandemic of the twenty-first century. It paralyzed global economy and affected each sector of the economy of the world. Most of the countries imposed lock down to slow down the outbreaks of Covid-19. In the beginning, Pakistan also followed the world measures and imposed lockdown in the whole country and suspended all economic activities. In May 2020 Government of Pakistan decided to put end to the lockdown against the recommendations of the health department and adopted micro lockdown and smart lock down in the badly affected areas by Covid -19 . This decision proved to be wise and appropriate as it saved the country from major outbreaks and hunger. According to the IMF, due to Covid-19 Pakistan faced the double digit inflation (10.7\%) and negative economic growth $0.4 \%$. It indicates that the Covid-19 pandemic has adversely affected the Pakistan economy.

The above analysis suggested that the government should pay proper attention to protect the population from the disease and hunger. There is a need to provide the vaccine of Covid-19 to every citizen without any discrimination. Furthermore, the government should implement the proper monetary and fiscal policies to stabilize the economy and protect it from high inflation as it badly affected the poors and the salaried class. In order to remove the current account deficit the government should take concrete measures which ensure increase in export and decrease in imports. 


\section{Reference}

1. Ahmed,A., \& Ahsan,H.(2011). Contribution of the services sector in the economy of Pakistan. Working Papers \& Research Reports.

2. Zaidi, S. A. (2006). Issues in Pakistan economy (2nd Rev. Ed.). Ka rachi, Pakistan: Oxford university.

3. Hasan,P.(1997). Learning from the past: A fifty-year perspective on Pakistan's development. The Pakistan Development Review, 36 (4), 355-402.

4. The New York Times (November 17,2021). Tracking coronavirus vaccinations around the world. https:/www.nytimes.com/interactive/2021/world/covid-vac cination stra cker.html.

5. Gul, A. (February 02, 2021). Covid-19 pandemic. https://www.voanews.com/a/covid-19-pandemic_pakistan-starts-covid19-inoculation-drive/6201529.html.

6. Kemal,M.A., \& Qadir, U. (2005). Real exchange ra te, exports, a nd imports movements: A trivariate analysis. The Pakistan Development Review, 177-195.

7. Khan, M.S. (2009). The 2008 oil price bubble policy, briefs PB09-19. Peterson Institute for International Economics.

8. Anwar, S., Abbas, Q., \& Ashfaq, M. (2017). Introduction to the Economy of Pakistan.

9. Tanoli, J. R. Comparison of Economic Growth under Democracy and Dicta torship: Comparing MusharrafEra to the Post 2007 Regim es.

10. Asghar, N., Batool, M., Farooq, F., \& Rehman, H. ur. (2020). Covid 19 Pandemic and Pa kistan Economy: A Prelimina ry Survey. Review of Economics and Development Studies, 6(2), 447-459. https://doi.org/10.47067/reads.v6i2.222.

11. Asian Development Bank (2020). COVID-19 Economic Impact Assessment Template. https://data.adb.org/media/4821/download.

12. Bloom, E., Wit, V. d., \& Jose, M. J.-S. (2005). Potential economic impact of an Avian Flu Pandemicon Asia. Asian Development B ank. https://www.think-asia.org/handle/11540/2165.

13. Brahmbhatt, M. (2005). Avian Influenza: Economic and Social Impacts. Speech. World Bank, Washington, D.C.

14. Cencia relli, O., Pietropa oli, S., Malizia, A., Ca restia, M., D’Amico, F., Sassolini, A., \& Gaudio, P. (2015). Ebola virus disea se 2013-2014 outbreak in west Africa: an analysis of the epidemic spread and response. International journal of microbiology, 2015.

15. Frith, J. (2012). The history of plague-part 1: the three great pandemics. Journal of Military and Veterans Health, 20(2), 11.

16. Haider, M. (2020). Pandemic losses can reach Rs2.5 trillion: experts," The News International, 03 April 2020, https://www.thenews.com.pk/print/638689-pandemiclosses-can-reach-rs2-5-trillion-experts. 
17. Iqbal, M.H.(1974). Pakistan's relations with Western Europe. Pakistan Horizon, 27(3), 70-80.or https://www.jstor.org/stable/41403857.

18. Ito, S. (1997). A fra mework for the comparative study of civilizations. Comparative Civilizations Review, 36(36), 3.

19. Javed, A. (2020) Economic Impact of Coronavirus and Revival Measures: Way Forward for Pakistan' Policy Review, Sustainable Development Policy Institute (SDPI)

20. Kanwal, S., Pitafi, A. H., Ma lik, M. Y., Khan, N. A., \& Rashid, R. M. (2020). Local Pakistani Citizens'Benefits and Attitudes Toward China-Pakistan Economic Corridor Projects. SAGE Open, 10(3), doi: $10.1177 / 2158244020942759$.

21. Karlsson, M., Nilsson, T., \& Pichler, S. (2014). The impact of the 1918 Spanish flu epidemic on economic performance in Sweden: An investigation into the consequences of an extraordinary mortality shock. Journal of health economics, 36, 1-19.

22. Lee, J.-W., \& McKibbin., J. W. (2004). Estimating the global economic costs of SARS. In S. Knobler, A. Mahmoud, S. Lem on, A. Ma ck, L. Sivitz, \& K. Oberholtzer(Eds.), Learning from SARS: Preparing for the next disease outbreak. Institute of Medicine (US) Forum on MicrobialThreats. https://www.ncbi.nlm.nih.gov/books/NBK92473/.

23. Lycett, S. J., Duchatel, F., \& Digard, P. (2019). A brief history of bird flu. Philosophical Transactions of the Royal Society B: Biological Sciences, 374(1775), 20180257. doi:10.1098/rstb.2018.0257.

24. Mohajan, H. K. (2020). Covid-19-the most fatal pandemic outbreak: An analysis of economic consequences. Annals of Spiru Haret University. Economic Series, 20(2), 127-145.

25. Pakistan Bureau of Statistic (2020). special survey for evaluating socioeconomic impact of covid-19 on wellbeing of people

26. Peiris, J. S. M., \& Poon, L. L. M. (2008). Severe Acute Respiratory Syndrome (SARS). Encyclopedia of Virology, 552560. doi:10.1016/b978-012374410-4.00780-9.

27. Rasmussen, S. A., Watson, A. K., \& Swerdlow, D. L. (2019). Middle Ea st Respiratory Syndrome (MERS). Emerging Infections 10, 73-104. doi:10.1128/microbiolspec.eil 0-0020-2016.

28. Rosen W.(2007). Justinian's Flea: The First Great Pla gueand the End of the Roman Empire. New York: Viking Penguin.

29. Rusdy Hartungi, (2006). Could developing countries ta ke the benefit of globalisation? International Journal of Social Economics, 33(11), 728 743. or http://dx.doi.org/10.1108/03068290610705652.

30. Khan,Z., \& Joseph, B. (2008). Pakistan after Musharraf: The media ta ke center stage. Journal of Democracy, 19(4), 32-37.

31. Shah, A. (2014). Constraining consolidation: military politics and democracy in Pakistan(2007-2013). Democratization, 2 1(6), 1007 1033. 
32. Sareen, S. (2020). COVID-19 and Pakistan: The Economic Fallout. ORF Occasional Papers, https://www. orfonline. org/research/covid19-and-pakistan-the-economic-fallout-67296.

33. WHO (2012) . Zoonotic Infections - Plague. Available at : http://www.who.int/vaccine_research/diseases/ zoonotic/en/index 3.html, accessed on 2.4.12.

34. Zaidi,S.A. 2021. A forgettable year for Pakistan's economy. East Asia Forum Economics, Politics and Public Policy in East Asia and the Pacific

35. Zeigler P. (1969). The Black Death. Godalming, Surrey: Bramley Books. 